\title{
Distribution and habitat suitability of two rare saproxylic beetles in Croatia - a piece of puzzle missing for South-Eastern Europe
}

\author{
Iva Rukavina ${ }^{(1-2)}$, \\ Fran Kostanjšek ${ }^{(3-4)}$, \\ Sven D Jelaska ${ }^{(1)}$, \\ Alja Pirnat ${ }^{(5)}$, \\ Lucija Šerić Jelaska ${ }^{(1)}$
}

\begin{abstract}
Due to habitat loss and fragmentation, the hermit beetle, Osmoderma eremita species complex (Coleoptera; Scarabidae) and the European red click beetle, Elater ferrugineus Linnaeus, 1758 (Coleoptera: Elateridae) are considered threatened in many European countries. Their presence in a large part of South-Eastern Europe has been sporadically recorded and these findings are mainly historical. Here we present the most recent findings of both species, assembled mainly throughout this first systematic study aiming to collect data on the hermit beetle within mapping and monitoring activities of saproxylic species protected by the European Habitat Directive (Annexes II and IV of Council Directive 92/43/EEC) within the Mediterranean, Continental and Alpine biogeographical regions of Croatia, and current literature data. To facilitate mapping activities and species range monitoring to improve the proper management of suitable habitats, we created habitat suitability maps using recent findings for both species, and predicted distribution were overlapped and analysed with historical data and protected areas. Most of the individuals were captured using flight intercept cross-vein funnel traps baited with pheromone for the hermit beetle placed within natural forest dominated by oak, beech and montane beech-fir forests, on sites with and without any forest management. Among set of 11 environmental variables, autumn precipitation, spring mean temperature and slope contributed most to the beetle distribution models. Data analyses indicated that the European red click beetle has much wider environmental envelope in which it can occur and that the hermit beetle can be used as surrogate species for the European red click beetle.
\end{abstract}

Keywords: European Red Click Beetle, Hermit Beetle, Mapping and Monitoring, MaxEnt, Natura 2000, Nature Conservation, Protected Areas

\section{Introduction}

The European hermit beetles belonging to Osmoderma eremita species complex (Coleoptera: Scarabaeidae, Cetoniinae) live in old hollow broad-leaved trees containing wood mould derived from the fungal decay of the dead heartwood and are obligate saproxylic species (Ranius et al. 2005). They can be found in the remnants of natural forest, but also in other habitats such as urban parks, trees around agricultural fields and along streams, etc. (Ranius et al. 2005). Although the taxonomy of this group has not been completely resolved, following Audisio et al. (2007, 2009), the Osmoderma eremita species complex consists of five species distributed in Europe: O. barnabita Motschulsky, 1845; O. cristinae Sparacio, 1994; O. eremita (Scopoli, 1763); O. italica Sparacio, 2000; and O. lassallei Baraud \& Tauzin, 1991, with O. barnabita present in Croatia (Alexander et al. 2010). Many studies conducted within European countries reported a strong decline in the distribution range of Osmoderma eremita species complex, and extinction in some areas, mainly due to habitat loss and fragmentation (Ranius \& Nilsson 1997, Cálix et al. 2018). Therefore, they have been added to the IUCN Red List with Near Threatened status (Alexander et al. 2010, Nieto \& Alex- ander 2010, Cálix et al. 2018) and listed in the Annexes II and IV of the EU Habitat Directive (European Commission 1992). O. barnabita, eastern hermit beetle, is known from the Central and East Europe, and Western Russia (Audisio et al. 2007, Alexander et al. 2010). However, the distribution range of $O$. barnabita in Croatia and western Balkan is poorly known (Alexander et al. 2010), with very scarce records for Croatia.

The European red click beetle, Elater ferrugineus Linnaeus, 1758 (Coleoptera: Elateridae), is a rare species associated with old hollow trees, whose larvae prey on the eggs and larvae of Scarabaeid and Lucanid beetles (Ranius et al. 2005, Barševskis \& Nitcis 2011). It is distributed in Europe, Caucasia and Asia Minor (Schimmel \& Tarnawski 2010), with deficient data on its distribution mainly in South-Eastern parts of Europe, including Croatia. As a consequence of scarce and old records, and lack of recent findings, $E$. ferrugineus has not been listed for Croatia in the latest relevant checklists (Cate 2007, 2013). The species can be found in old deciduous forests, parks, and wooded meadows (Barševskis \& Nitcis 2011, Platia et al. 2015). The larvae of the species live in rotten wooden substrate inside of deciduous trees, e.g., oak and 


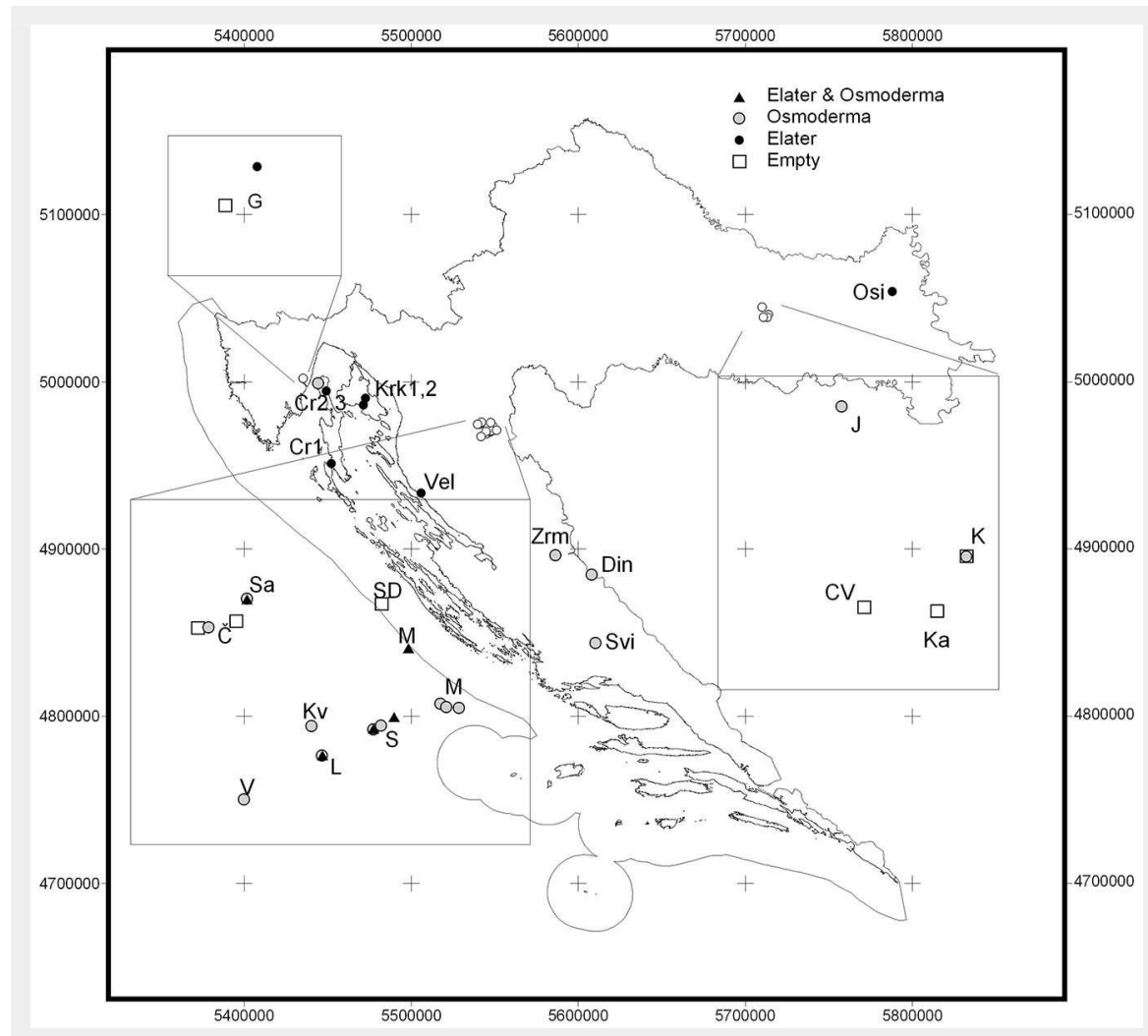

Fig. 1 - Map of the recent findings of Elater ferrugineus and Osmoderma barnabita in Croatia. Symbols of locations (see Tab. 1 and Tab. 2) at the Papuk Nature Park: (CV): Češljakovačka visoravan; (J): Jankovac virgin forest; (K): Kozjak; (Ka): Kaptol; at the Plitvice Lakes National Park: (C): Čorkova uvala virgin forest; (Kv): Kameni Vrh; (L): Liman-draga; (M): Medvedak; (S): Stubica; (Sa): Sartuk; (SD): Sužanjska Draga; (V): Vreline; at Mt. Učka: (G): Grbac. Sampling sites within each location are represented as symbols: squares - empty trap/s; triangle - traps with $O$. barnabita and E. ferrugineus recorded (Elater \& Osmoderma); grey circle - traps with records of $O$. barnabita only (Osmoderma); black diamond - traps with records of E. ferrugineus only (Elater) (see the legend above).

beech, which have been inhabited by primary consumers like the xylophagous larva of Osmoderma, Cetonia, Potosia (Cetoniinae) and Dorcus (Lucanidae) species (Schimmel \& Tarnawski 2010). Since E. ferrugineus is also associated with old hollow trees which are usually scattered across the landscape at the very low densities, it is thus negatively affected by the loss of such trees caused by, e.g., forestry management practice and deforestation (Musa et al. 2013). Therefore, E. ferrugineus has been added to the IUCN Red List of European saproxylic beetles with the Near Threatened status (Nieto \& Alexander 2010, Cálix et al. 2018) and it is also included in the Red Lists of protected species in many countries (Barševskis \& Nitcis 2011, Platia et al. 2015).

In this paper, we presented the recent findings of $O$. barnabita and $E$. ferrugineus during field mapping and monitoring of saproxylic beetles, listed at Annex II and IV of EU Habitat Directive (Council Directive 92/43/EEC), in three areas (Fig. 1) located in the Mediterranean, Continental and Alpine bio-geographical regions in Croatia aiming to extend the knowledge in their distribution. Data were used to model habitat suit- ability maps in order to direct future monitoring activities. Some of those data represents the first findings for certain parts of Croatia. Old records of these saproxylic species in Croatia, dating from the end of the $19^{\text {th }}$ and from the $20^{\text {th }}$ centuries (see Tab. S1 in Supplementary Material), were presented on the map as well, and together with nature protected areas were overlapped with habitat suitability map to suggest future studies and nature protection actions.

\section{Material and methods}

\section{Study areas}

The study has been conducted in mountain forests (Fig. 1) within all three biogeographical areas present in Croatia: (i) Mt. Učka in western Croatia, within Mediterranean biogeographical region; (ii) Papuk Nature Park at Mt. Papuk in eastern Croatia, in Continental region; and (iii) Plitvice Lakes National Park in Alpine region.

Mount Učka is situated in the north eastern part of the Istrian peninsula in Croatia, near the Adriatic Sea, and represents a part of Mediterranean karst with a strong Mediterranean influence on climate and floral elements. Two study sites were situated in the area called Grbac, in the southern part of Mt. Učka, close to the borders of Učka Nature Park, placed on moderate to steep slope, with south exposition, and the elevation of $300 \mathrm{~m}$ a.s.l. The ground is shallow to medium deep brown soil on flysch sediment with the partial outbreak of rocks and screes. The present forest community is Seslerio autumnalis-Ostryetum Horvat \& Horvatić ex Horvat et al. (1974) densely overgrown with bushes. Hop-hornbeam (Ostrya carpinifolia Scop.) and manna ash (Fraxinus ornus L.) grow alongside downy oak (Quercus pubescens Wild.). Pines (Pinus sp.) also occur. Shrub layer consisted of sprouts of above-listed tree species and juniper (Juniperus sp.), terebinth (Pistacia terebinthus L.), European smoke tree (Cotinus coggygria Scop.) and common dogwood (Cornus sanguinea L.). The study sites were situated in the state-owned coppice forests managed by Croatian Forest Ltd. National Company, positioned in the vicinity of Nature Park Učka, that is part of the Natura 2000 network.

The Papuk Nature Park is situated on the Mt. Papuk, in the Continental biogeographical region, in the Eastern Croatia, surrounded with lowland mainly used as an agricultural land. The Papuk is mostly covered by forest with the sessile oak (Quercus petraea [Mattuschka] Liebl.) dominant up to $350 \mathrm{~m}$ a.s.l. Beech trees (Fagus sylvatica L.) cover more than $50 \%$ of the forested area, whereas mixed beech-fir forests grow in areas higher than $700 \mathrm{~m}$ a.s.l. Although commercially managed by Croatian Forests Ltd., except "Jankovac" virgin forest area, all forests have a natural composition of tree species. The deciduous forests are managed as even-aged stands, while the beech-fir forests are managed following the selective logging system. Beech stand at Jankovac area represents secondary virgin forest, spread over 660 ha, that has been left unmanaged for more than 160 years. The Papuk Nature Park is a part of the Natura 2000 network, and based on one old literature record of hermit beetle (Koča 1900) and accidental finding of one specimen in Jankovac forest on July $11^{\text {th }}, 2008$ (Vlatka Dumbović Mazal private collection), this area has been designated as a site of community importance $(\mathrm{SCl})$ in order to ensure the favourable conservation status of the species.

The Plitvice Lakes National Park has a unique landscape and has been added to the UNESCO World Heritage list. The Plitvice area is a part of the Lika County, belonging to the Alpine biogeographical region. It is situated in the southern parts of Mala Kapela Mountain chain, ranging from 450 to $1280 \mathrm{~m}$ a.s.l., with limestone and dolomite rocks. Around three-quarters of the park surface has been covered with the forests in their various stages from scrubs to the virgin forests. From 1994 until nowadays, according to the Nature Protection Act (The Official Gazette of the Republic of 
Croatia No. 30/94 and 72/94), forests within the Park have been left to develop naturally. Beech and beech-fir forests represent climate-vegetation with predominant beech forest with dead nettle Lamio orvalae - Fagetum sylvaticae (Horvat, 1938), Borhidi 1963. In the dependence to the relief, geology, soil depth and moisture, a range of other forests have been developed as well (e.g., vegetation with dominant willow, European alder, hop-hornbeam, spruce, silver pine, etc.). 0 . barnabita was mentioned for Plitvice area (Croatia: Plitvice, July $30^{\text {th }}, 2002$ ) in the paper of Audisio et al. (2009) without providing more precise location, and there was one accidental finding of dead insect in virgin forest in Corkova uvala area, reported to the National Park authorities in season $2006 / 07$, without precise date (collected by Krešimir Culinović). Based on those data on O. barnabita, Plitvice NP has been designated as a site of community importance $(\mathrm{SCl})$ in order to ensure the favourable conservation status of the species.

\section{Sampling methods}

Several sampling methods (counts on transects, ground and tree pitfall traps and flight intercept window traps) were used in studied areas as a part of three projects aiming for mapping and monitoring of saproxylic beetles listed at Annex II and IV of EU Habitat Directive (Council Directive 92/43/EEC): Lucanus cervus (Linnaeus, 1758) (Lucanidae), Morimus asper funereus Mulsant, 1863 (Cerambycidae), Osmoderma eremita species complex, Rhysodes sulcatus (Fabricius, 1787) (Rhysodidae) and Rosalia alpina (Linnaeus, 1758) (Cerambycidae), run by Croatian Ecological Society and Faculty of Science in Zagreb. Of those, tree pitfall traps and flight intercept cross-vein funnel traps with pheromone were efficient in sampling O. barnabita and E. ferrugineus, and will be presented in detail.

At Mt. Učka, field research was conducted according to the national monitoring program for stag beetles Lucanus cervus in the Mediterranean biogeographical region (Šerić Jelaska 2013, Katušić et al. 2017) from June $12^{\text {th }}$ until July $05^{\text {th }}$ in 2014. Two transects, Grbac 1 (G1) and Grbac 2 (G2), each of $200 \mathrm{~m}$ in length, were chosen following the forest road. Stumps and dry trees were not numerous, but there were a greater number of old hollow trees: 24 hollow trees, 11 dry trees and three stumps were counted alongside the chosen transects. The tree pitfall traps were made of plastic bottles $(2 \mathrm{~L})$ with the upper part cut and placed inside the lower part making a plastic pot with a funnel. Overall, 24 tree traps were employed during three weeks period, twelve traps along each transect were attached to the oak tree trunks along the transect path, at 1.5 to $2 \mathrm{~m}$ of the tree height (Fig. 2), as recommended by Šerić Jelaska (2013) and Vrezec et al. (2013). In three traps, the fruit (chopped peaches and bananas) was used as a bait, in three

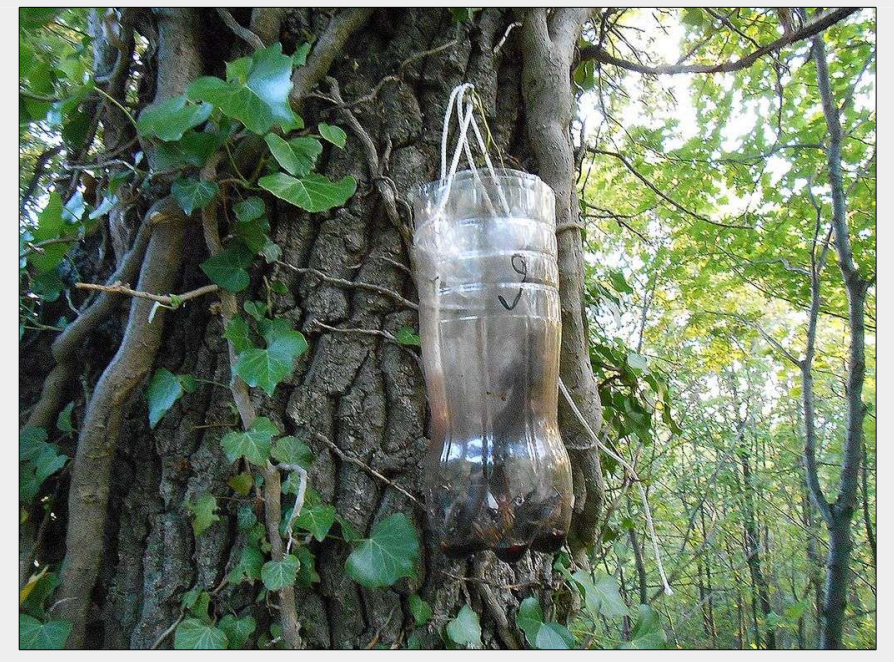

Fig. 2 - Tree pitfall trap with wine and vanilla sugar and extract.

wine flavoured with vanilla extract and vanilla sugar, three traps had grated ginger and three traps without any bait were used as a reference (Harvey et al. 2011, Šerić Jelaska 2013, Vrezec et al. 2013).

At the Papuk Nature Park and Plitvice Lakes National Park, besides methods used for monitoring of the stag beetle following the national protocol (Šerić Jelaska 2013, Katušić et al. 2017) similar to that conducted at two sites on Mt. Učka, flight intercept cross-vein funnel traps with pheromone (Svensson \& Larsson 2008 - Fig. 3) were utilised aiming to record hermit beetle. Flight intercept cross-vein funnel traps (Fig. 3) were baited with the racemic (R)(+)- $\gamma$-decalactone (Larsson et al. 2003). The pheromone was applied to a small piece of cotton which was protruded from a small tube that was hanged in the middle of the plastic cross and was re-applied during visits. The traps were hooked at the height around 2 to 2.5 meters on tree branches, in a small forest openings (Fig. 3).

Five flight intercept cross-vein funnel traps with the pheromone were placed at each of four locations at the Mt. Papuk: Češljakovačka visoravan (CV) and Jankovac, a secondary virgin forest $(J)$ in beech stands, and Kaptol (Ka) and Kozjak (K) in the sessile oak forests, with 20 traps overall (Tab. 1). The traps were exposed from June $19^{\text {th }}$ until $24^{\text {th }}$ and again from July $1^{\text {st }}$ until $6^{\text {th }}$ in 2015 (10 days in total) and visited every day.

In Plitvice Lakes National Park, overall twenty flight intercept cross-vein funnel traps with the same pheromone were employed at eight locations: Stubica (S), Medvedak (M) and Liman-draga (L) near Plitvički Ljeskovac village placed in a beech forest with dead nettle; and other five sites, Corkova uvala virgin forest (C), Kameni Vrh (Kv), Sartuk (Sa), Sužanjska Draga (SD) and Vreline (V) positioned within beech-fir mixed forests (Tab. 1). The traps were exposed between June $24^{\text {th }}$ and August $3^{\text {rd }}$ in 2016 and visited every three to ten days. The traps that were exposed for the longest period were checked seven times. Of the five traps placed in Čorkova uvala virgin forest, one trap was left without pheromone and was exposed from June $25^{\text {th }}$ until July $14^{\text {th }}$ (for 19 days).

Identification of collected specimens was done based on the following publications: Freude et al. (1979) and Schimmel \& Tarnawski (2010) for E. ferrugineus, and Spara-

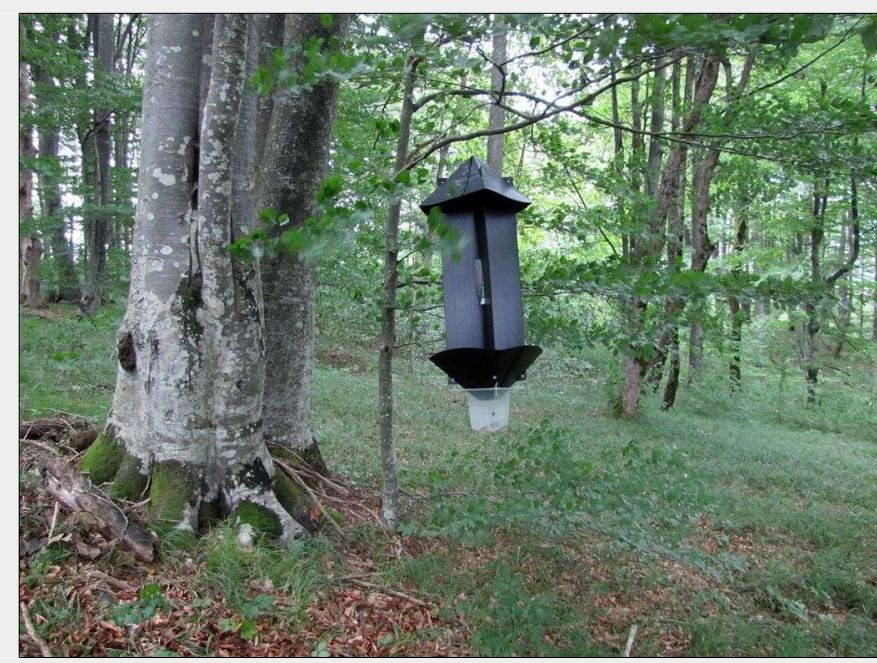

Fig. 3 - Flight intercept trap with pheromone applied on the cotton pad placed in the middle of the crossed plastic panels. 
cio (2000), Han et al. (2017) and Maurizi et al. (2017) for Osmoderma barnabita. Pronotum and elytra of $E$. ferrugineus are variable in colour. Besides specimen with nominal variety (var. ferrugineus) with red pronotum and elytra, those with black pronotum and red elytra have been recorded at Plitvice sites. The external characters of the examined specimens from Plitvice with black pronotum and red elytra fit the description of E. ferrugineus by Schimmel \& Tarnawski (2010) belonging to var. occitanicus Villers, 1789 (Merzijevskis \& Tamutis 2010, G. Platia, personal communication).

\section{Assessment of distribution patterns}

Given the lack of current data on the presence of $O$. barnabita and $E$. ferrugineus in Croatia, we used data from our study (Tab. 1) and available records published after 2002 (that were not listed in Ranius et al. 2005): Schimmel \& Tarnawski 2010, Rojko \& Koren 2011, Batrnek et al. 2017, Delić et al. 2017 (Tab. 2), together with unpublished recent records of local entomologists and data from several collections (BIUS Association at the University of Zagreb, Biology Department at the University JJ Strossmayer in Osijek, G. Platia private collection - Tab. 2), in order to develop habitat suitability maps for all of Croatia us- ing the software MaxEnt (Phillips et al. 2006) and to estimate areas that could be potentially occupied by the species. As independent variables or descriptors, we used 11 environmental variables that represent the climatic conditions (amount of precipitation and average temperature for autumn, winter, spring and summer seasons) and topographic (slope and aspect). Aspect values because of their "circularity" (e.g., $1^{\circ}$ and $359^{\circ}$ representing an almost identical aspect), were transformed by calculating the sine and cosine of aspect values, forming two variables ranging from -1 to 1 , representing an inclination from north (cosine) and from east (sine) as in Guisan et al. (1999) and Jelaska et al. (2003). All environmental variables were with $300 \mathrm{~m}$ spatial resolution (source: the Department of Biology, Faculty of Science, University of Zagreb). The resulting MaxEnt maps, with their logistic outputs (i.e., values ranging from 0 to 1) were reclassified to binary (o: non-suitable habitat; 1: suitable habitat) grids using the customized threshold values. Instead of using a case sensitive adjusted threshold values as in Katušić et al. (2017), who dealt also with rare species with very scarce data, we used conservative value of 0.5 as in Sadeghi \& Malekian (2017). The smallest logistic output value for 0 . barnabita was 0.117 on locations used to construct the models, which seemed as it could yield too large overestimation of the model for $O$. barnabita. The obtained two reclassified MaxEnt models were spatially overlapped, and mutual and unique areas of suitable habitats for both beetles were calculated.

Historical data were assembled by searching: (i) literature available within national scientific and university libraries and via internet; (ii) collections deposited in national museums and universities, private collections and museum collections available online; (iii) in personal communication with other entomologists and curators from Croatia and neighbouring countries. Historical records have been listed in Tab. S1 (Supplementary material). Identification of specimens belonging to historical data deposited in museum collections were not revised within this study; therefore for historical data we used names Osmoderma eremita complex species and "hermit beetle". To test the habitat suitability models, we used geo-referenced historical data from (i) literature dating before 2002: Ranius et al. (2005), with compilation of records of hermit beetle within European countries until 2002; Koča (1900), Depoli (1928), Strbac (1983), Schimmel \& Tarnawski (2010)

Tab. 1 - Records of E. ferrugineus and O. barnabita using traps at each site on Mt. Učka, Mt. Papuk and Plitvice Lakes, number of beetles observed per trap per day, dates of records and altitudes of the sites.

\begin{tabular}{|c|c|c|c|c|c|c|c|c|}
\hline Location & $\begin{array}{l}\text { Trapping } \\
\text { method }\end{array}$ & Area & $\begin{array}{l}\text { Trapping } \\
\text { sites }\end{array}$ & $\begin{array}{l}\text { E. ferrugineus } \\
\text { ( } \mathrm{n} \text { ind.) }\end{array}$ & $\begin{array}{l}\text { O. barnabita } \\
\text { ( } \mathrm{n} \text { ind.) }\end{array}$ & $\begin{array}{l}\text { No.Traps·Days } \\
\text { (n ind/trap·day) }\end{array}$ & $\begin{array}{l}\text { Date of } \\
\text { record } \\
\text { (D/M/Y) }\end{array}$ & $\begin{array}{l}\text { Altitude } \\
\text { (m a.s.l.) }\end{array}$ \\
\hline \multirow[t]{2}{*}{ Mt. Učka } & \multirow{2}{*}{$\begin{array}{l}\text { Wine baited tree } \\
\text { traps }\end{array}$} & \multirow[t]{2}{*}{ Grbac } & G1 & 1 & 0 & $12 \cdot 24(0.007)$ & $24 / 06 / 2014$ & 300 \\
\hline & & & G2 & 0 & 0 & $12 \cdot 24$ & - & 160 \\
\hline \multirow[t]{6}{*}{ Mt. Papuk } & \multirow{2}{*}{$\begin{array}{l}\text { Baited tree traps } \\
\text { ( } 4 \text { with fruit, } 4 \text { with } \\
\text { wine and } 4 \text { empty ) }\end{array}$} & Kozjak & $\mathrm{K}$ & 0 & 0 & $12 \cdot 10$ & - & 568 \\
\hline & & Kaptol & $\mathrm{Ka}$ & 0 & 0 & $12 \cdot 10$ & - & 375 \\
\hline & \multirow{4}{*}{$\begin{array}{l}\text { Traps with } \\
\text { pheromones }\end{array}$} & Jankovac & $\mathrm{J}$ & 0 & 2 & $5 \cdot 10(0.04)$ & $06 / 07 / 2015$ & 556 \\
\hline & & Kozjak & $\mathrm{K}$ & 0 & 2 & $5 \cdot 10(0.04)$ & $06 / 07 / 2015$ & 568 \\
\hline & & Kaptol & $\mathrm{Ka}$ & 0 & 0 & $5 \cdot 10$ & - & 375 \\
\hline & & $\begin{array}{l}\text { Češljakovačka } \\
\text { visoravan }\end{array}$ & $\mathrm{CV}$ & 0 & 0 & $5 \cdot 10$ & - & 368 \\
\hline \multirow[t]{17}{*}{ Plitvice NP } & \multirow[t]{16}{*}{$\begin{array}{l}\text { Traps with } \\
\text { pheromones }\end{array}$} & \multirow[t]{3}{*}{ Medvedak } & M1 & 0 & 2 & $2 \cdot 19(0.053)$ & $\begin{array}{c}05 \& 13 / 07 / \\
2016\end{array}$ & 649 \\
\hline & & & M2 & 3 & 1 & $1 \cdot 10(0.400)$ & $31 / 07 / 2016$ & 607 \\
\hline & & & M3 & 0 & 1 & $1.8(0.125)$ & $21 / 07 / 2016$ & 662 \\
\hline & & \multirow[t]{2}{*}{ Liman draga } & $\mathrm{L} 1$ & 0 & 2 & $1 \cdot 7(0.286)$ & $12 / 07 / 2016$ & 720 \\
\hline & & & L2 & 1 & 2 & $1 \cdot 7(0.429)$ & $12 / 07 / 2016$ & 713 \\
\hline & & \multirow[t]{4}{*}{ Stubica } & S1 & 0 & 1 & $1 \cdot 10(0.100)$ & $31 / 07 / 2016$ & 715 \\
\hline & & & S2 & 2 & 1 & $1 \cdot 12(0.250)$ & $27 / 07 / 2016$ & 712 \\
\hline & & & S3 & 0 & 1 & $1 \cdot 10(0.100)$ & $31 / 07 / 2016$ & 639 \\
\hline & & & S4 & 1 & 1 & $1 \cdot 16(0.125)$ & $21 / 07 / 2016$ & 622 \\
\hline & & \multirow[t]{2}{*}{ Čorkova uvala } & $\mathrm{C} 1$ & 0 & 0 & $1 \cdot 4$ & - & 864 \\
\hline & & & $\mathrm{C} 2$ & 0 & 3 & $3.9(0.111)$ & $14 / 07 / 2016$ & 878 \\
\hline & & Sužanjska draga & SD & 0 & 0 & $1 \cdot 4$ & - & 712 \\
\hline & & Kameni Vrh & $\mathrm{Kv}$ & 0 & 3 & $1.7(0.429)$ & $12 / 07 / 2016$ & 844 \\
\hline & & \multirow[t]{2}{*}{ Sartuk } & Sa1 & 1 & 4 & $1 \cdot 19(0.263)$ & $14 / 07 / 2016$ & 814 \\
\hline & & & Sa2 & 0 & 1 & $1 \cdot 10(0.100)$ & $05 / 07 / 2016$ & 831 \\
\hline & & Vreline & $\mathrm{V}$ & 0 & 1 & $1 \cdot 26(0.038)$ & $31 / 07 / 2016$ & 782 \\
\hline & $\begin{array}{l}\text { Trap with no } \\
\text { pheromones }\end{array}$ & Čorkova uvala & $\mathrm{C} 3$ & 0 & 0 & $1 \cdot 19$ & - & 927 \\
\hline Sum & & - & - & 9 & 28 & - & 293 & - \\
\hline \multicolumn{2}{|c|}{ Other observations } & Medvedak (M) & $\begin{array}{l}\text { Hiking } \\
\text { trail }\end{array}$ & 0 & 1 & - & $03 / 07 / 2016$ & 723 \\
\hline \multicolumn{2}{|c|}{ Overall no. of records } & - & - & 9 & 29 & - & - & - \\
\hline
\end{tabular}


Tab. 2 - Recent records of E. ferrugineus and O. barnabita (from 2002 to 2017) from private collections, recent publications and personal observations by entomologists, with location and site abbreviation used for mapping, number of beetles observed, date of records and source of the information.

\begin{tabular}{|c|c|c|c|c|c|c|}
\hline Region & Area & Abbreviation - Site & $\begin{array}{l}\text { E. ferrugineus } \\
\text { ( } \mathrm{n} \text { ind.) }\end{array}$ & $\begin{array}{l}\text { O. barnabita } \\
\text { ( } \mathrm{n} \text { ind.) }\end{array}$ & $\begin{array}{l}\text { Altitude } \\
\text { (m a.s.l.) }\end{array}$ & Source / Year of observation \\
\hline \multirow[t]{11}{*}{ Mediterranean } & \multirow[t]{3}{*}{ Krk Island } & Krk1-Krk & 1 & 0 & 50 & Kostanjšek, pers. comm., 2009 \\
\hline & & \multirow[t]{2}{*}{ Krk2-Punat } & 2 & 0 & 20 & $\begin{array}{l}\text { Schimmel \& Tarnawski (2010): leg P } \\
\text { Rapuzzi, 2002, } 2003 \text { (in G Platia coll). }\end{array}$ \\
\hline & & & 1 & 0 & - & $\begin{array}{l}\text { coll. G Platia: leg Padovani \& } \\
\text { Malmusi, } 2005 \text { (Krk Island) }\end{array}$ \\
\hline & Lošinj Island & Cr1-Osor & 1 & 0 & 20 & Kostanjšek, pers.comm.,2010 \\
\hline & \multirow[t]{3}{*}{ Cres Island } & Cr2-Porozina & 0 & 2 & 20 & Katušić, pers. obs., 2009, 2016 \\
\hline & & \multirow[t]{2}{*}{ Cr3-Sv. Petar } & 1 & 0 & 100 & Kostanjšek, pers. comm., 2010 \\
\hline & & & 1 & 0 & 400 & $\begin{array}{l}\text { Coll G Platia, leg L Saltini in } 2012 \\
\text { (Northern Cres Island) }\end{array}$ \\
\hline & \multirow[t]{2}{*}{ Kvarner } & $\begin{array}{l}\text { Vel - Mt. Velebit near } \\
\text { Karlobag }\end{array}$ & 1 & 0 & 400 & $\begin{array}{l}\text { Schimmel \& Tarnawski (2010): leg } \\
\text { Padovani \& Malmusi } 2009 \text { (in G Platia } \\
\text { coll) }\end{array}$ \\
\hline & & Vel - Senj, Stolac & 1 & 0 & - & coll G Platia, leg P Rapuzzi 2008 \\
\hline & Svilaja & Svi - Grabovac Cesma & 0 & 1 & 371 & Delić et al. (2017), 28. VI. 2008 \\
\hline & Zrmanja & Zrm-Zrmanja spring & 0 & 1 & - & Rojko \& Koren (2011), 11. VII. 2011 \\
\hline \multirow{2}{*}{ Continental } & Mt Papuk & J- Jankovac & 0 & 1 & 550 & leg V Dumbović Mazal, 11. VII 2008 \\
\hline & Osijek & Osi - Osijek & 7 & 0 & 90 & $\begin{array}{l}\text { Batrnek et al. (2017) (Town Parks } \\
\text { Perivoja kralja Tomislava i Perivoja } \\
\text { kralja Petra Krešimira IV), 5.VII- } 19 . \\
\text { VII } 2017\end{array}$ \\
\hline \multirow[t]{4}{*}{ Alpine } & Plitvice Lakes & C - Čorkova uvala & 0 & 1 & 860 & leg. K. Culinović 2006 or 2007 \\
\hline & & Plitvice Lakes & & & & Audisio et al. (2007) \\
\hline & Mt. Velebit & $\begin{array}{l}\text { Vel- Mt. Velebit, } \\
\text { Šušanj (Gospić) }\end{array}$ & 1 & 0 & 500 & $\begin{array}{l}\text { coll G Platia: leg Malmusi \& Poloni, } \\
28 . V I .-14 . \text { VII } 2011\end{array}$ \\
\hline & Mt. Dinara & Din-Brezovac & 0 & 2 & 1050 & $\begin{array}{l}\text { Association BIUS coll. University of } \\
\text { Zagreb, leg Skejo and Rebrina, August } \\
2012\end{array}$ \\
\hline \multicolumn{2}{|c|}{ No. of individuals } & - & 17 & 9 & - & - \\
\hline
\end{tabular}

with the records of E. ferrugineus; (ii) entomology collections: Varaždin Town Museum (with record of hermit beetle within Košćec collection that were not included in Ranius et al. 2005) and Natural History Museum in Zagreb (in Igalffy, Koča and Korlević collections), Faculty of Forestry in Zagreb (Hensch collection) and G. Platia private collection with data on $E$. ferrugineus (see Tab. S1 in Supplementary material). Majority of those data were around 100 years old, and all localities were described with rather general toponyms. Hence, instead of spatially overlapping of point localities assigned to each historical data with habitat suitability models, we have identified the $10 \mathrm{~km}^{2}$ EEA reference grid cells (EEA 2013) that contain historical data and overlapped those grid cells with the MaxEnt models to estimate the amount of their congruency.

\section{Results}

\section{Field records of Osmoderma barnabita} in study areas

Overall 29 individuals were recorded during a field survey in the Papuk Nature Park in 2015 and in the Plitvice Lakes National Park in 2016. There were no records of hermit beetle on Mt. Učka during the project in 2014 (Tab. 1, Fig. 1).

Four individual species were caught using flight intercept cross-vein funnel traps with pheromone placed in two sites on Mt. Papuk: in secondary virgin beech forest in Jankovac area and in oak forest mixed with beech trees in Kozjak area, the same day on July $6^{\text {th }}, 2015$ (Tab. 1, Fig. 1).

In the Plitvice Lakes National Park all but one $O$. barnabita individuals were caught using flight intercept cross-vein funnel traps with pheromone. Observations of 24 individuals occurred between $5^{\text {th }}$ and $31^{\text {st }}$ of July, at seven out of eight locations (Tab. 1, Fig. 1, Fig. 4), three sites within beech forest with dead nettle (Medvedak, M; Stubica, S; Liman-draga, L) and four (Virgin for-

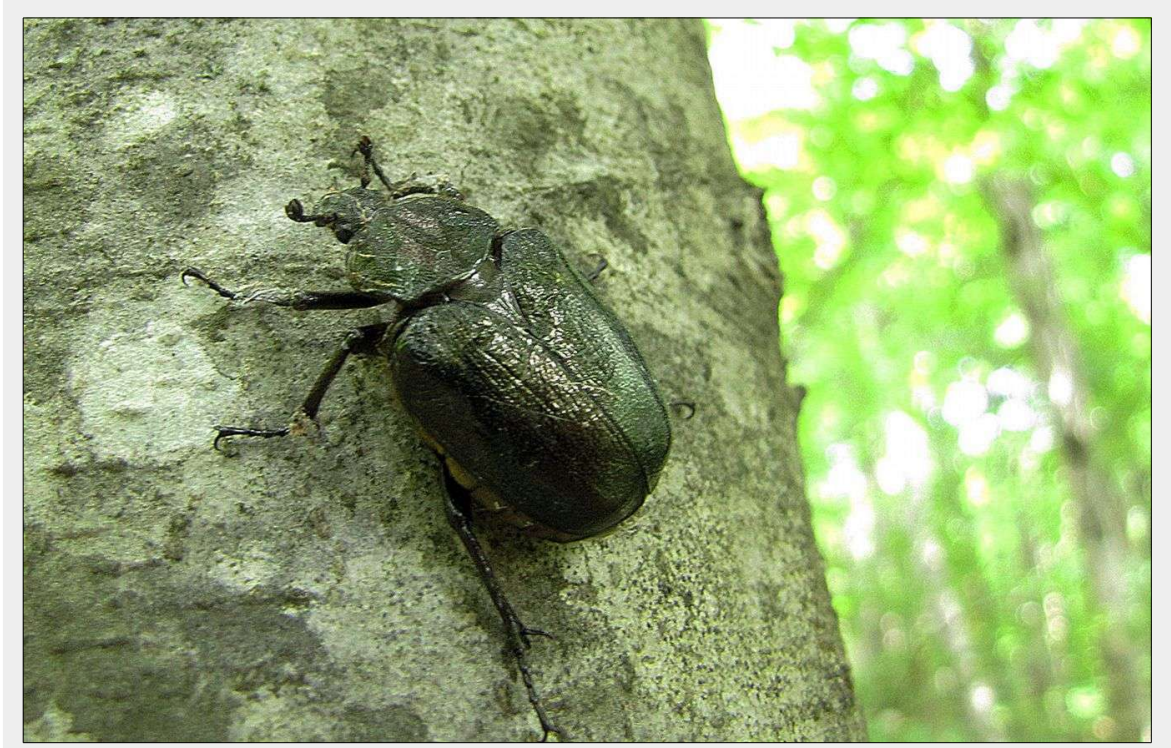

Fig. 4 - Eastern hermit beetle Osmoderma barnabita caught at the Plitvice Lakes $\mathrm{Na}$ tional Park, Croatia. 


\section{Osmoderma barnabita}

Marginal response curves aprec
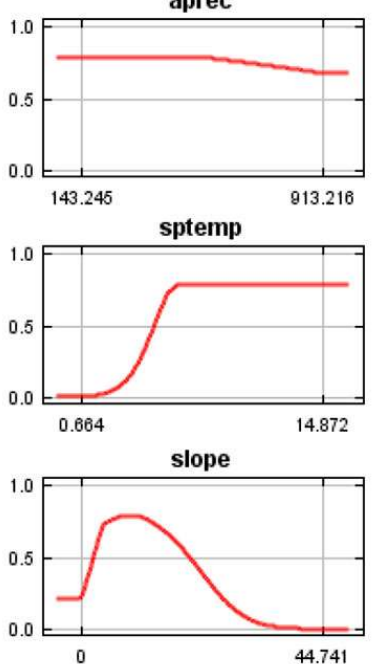

One variable model curves aprec
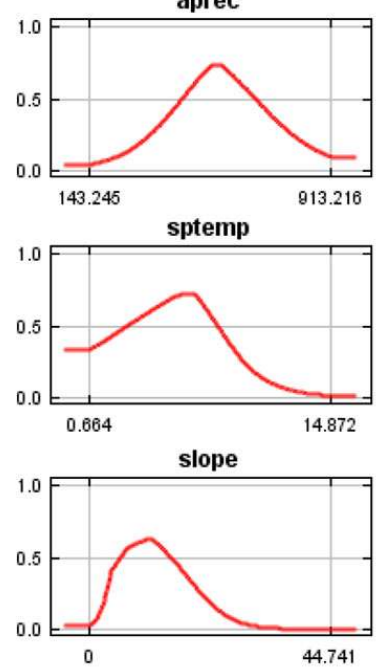

\section{Elater ferrugineus}

Marginal response curves aprec
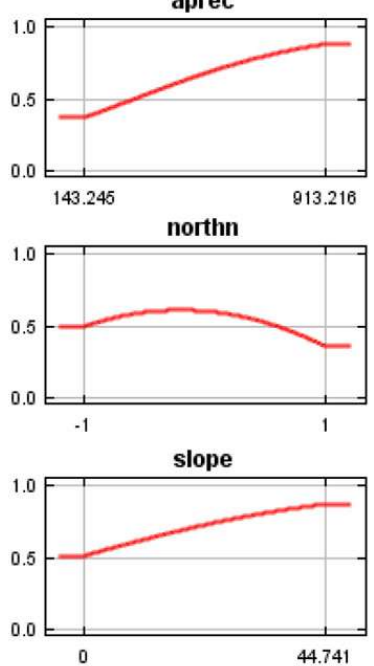

One variable model curves aprec
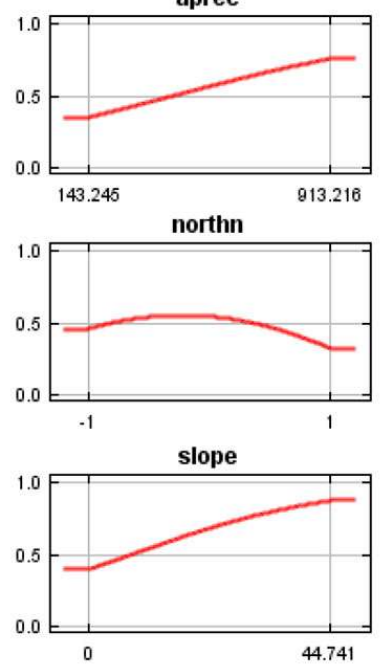

Fig. 5 - Response curves of three environmental variables that contributed most to MaxEnt models for Elater ferrugineus and Osmoderma barnabita. (aprec - autumn precipitation; sptemp - spring mean temperature; slope - slope of the terrain; northn - inclination from the north).

est Čorkova uvala, C; Sartuk, Sa; Vreline, V; Field records of Elater ferrugineus in Kameni $\mathrm{Vrh}, \mathrm{Kv}$ ) within the beech-fir forest. study areas

One individual was observed in the beech Overall 9 individuals of E. ferrugineus forest in Medvedak area at $723 \mathrm{~m}$ a.s.l. in were recorded, one on Mt. Učka in 2014 Plitvice Lakes NP on July $13^{\text {th }}, 2016$, when and eight in the Plitvice Lakes National landed on a ground, around noon, during Park in 2016. There were no records of $E$. sunny day.

ferrugineus in traps used in Papuk area dur-

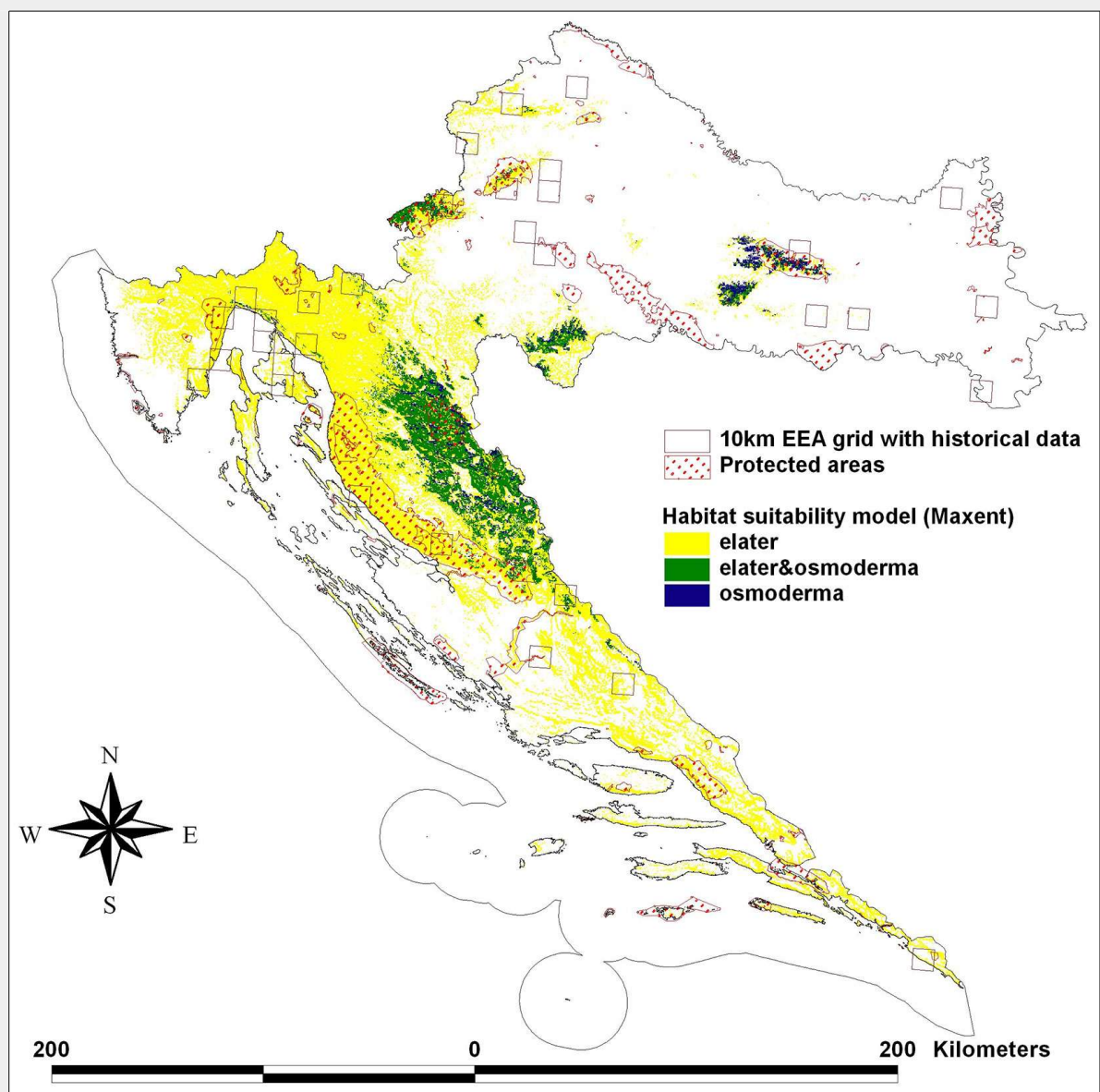

ing the project in 2015 (Tab. 1, Fig. 1). On Mt. Učka, on June $24^{\text {th }}, 2014$ one individual was caught in tree pitfall trap baited with wine flavoured with vanilla extract and attached on downy oak tree Quercus pubescens with $77 \mathrm{~cm}$ in diameter (Fig. 2).

In the Plitvice Lakes National Park, eight

Fig. 6 - MaxEnt habitat suitability derived maps based on variables representing climatic and relief condition. 10 $\mathrm{km}^{2}$ grid cells containing historical data on hermit and the European red click beetles and protected areas are superimposed (for more details, see Methods section). 
individuals were caught ( 7 females and one male) using flight intercept cross-vein funnel traps with pheromone (Fig. 3), at four out of eight locations: Stubica (S), Medvedak (M), Liman-draga (L) near Plitvički Ljeskovac village south of Prošćansko Lake in beech forest with dead nettle and at Sartuk (Sa) in beech-fir forest. Individuals were caught during four visits: on July $12^{\text {th }}$, $14^{\text {th }}, 21^{\text {st }}$ and $31^{\text {st }}$ in 2016 (Tab. 1, Fig. 1). In the same sites, $O$. barnabita was caught as well (Tab. 1).

\section{Environmental response and habitat suitability}

Obtained AUC on training data was 0.784 for $E$. ferrugineus, and 0.948 for O. barnabita. For both species, three environmental variables contributed to the MaxEnt models with more than $10 \%$, with identical two environmental variables, namely: autumn precipitation ( $E$. ferrugineus $41.3 \%$; $O$. barnabita $10.4 \%$ ); and the slope (E. ferrugineus $36.7 \%$; O. barnabita 32.5\%). Northness contributed further $20.3 \%$ to the model for $E$. ferrugineus, while spring temperature contributed $28.5 \%$ for O. barnabita. Based on the environmental variables response curves (Fig. 5), it seems that wetter autumns on steeper areas are favourable for the potential occurrence of $E$. ferrugineus, or at least its habitats. For $O$. barnabita response curves are not so straightforward, showing mostly a unimodal response.

Habitat suitability maps for $E$. ferrugineus and $O$. barnabita beetles are shown in Fig. 6. Suitable habitats are expected to be found on $15,125 \mathrm{~km}^{2}$ for $E$. ferrugineus, and on $3,163 \mathrm{~km}^{2}$ for $\mathrm{O}$. barnabita, with those two overlapping on $2,424 \mathrm{~km}^{2}$. Historical data (from 2002 and older) for hermit beetle (33 locations) and E. ferrugineus (8 locations - see Tab. S1 in Supplementary Material) were within 33 of the $10 \mathrm{~km}^{2}$ grid cells, out of which 27 has overlapped with the combined MaxEnt map (Fig. 6) for both species.

\section{Discussion}

\section{Findings of hermit and the European} red click beetle in Croatia

The fact that this was the first systematic survey conducted in Croatia focusing on hermit beetle may explain why data on this species have been scarce. Most of the previous findings are accidental records. Besides findings of $O$. barnabita from our research in Papuk and Plitvice Lakes areas, there were several recent records that were included in habitat suitability analyses from other locations: Mt. Svilaja in 2008 (Delić et al. 2017), on a willow tree close to the spring of Zrmanja river (Rojko \& Koren 2011), Kvarner area and Northern Adriatic Islands (L. Katušić and F. Kostanjšek personal communications, G. Platia collection) belonging to Mediterranean biogeographical region; in the beech forest in Mt. Dinara and Velebit (BIUS Association and G. Platia collections) within Alpine biogeographical region. In Ranius et al. (2005), the latest paper in which the distribution of the species complex across Europe were presented, 31 locations for Croatia were listed based on data from the Croatian's museums, private collections and literature for period between 1982 and 2002. Since the authors in Ranius et al. (2005) did not include data from Franjo Košćec collection deposited in Varaždin Town Museum, we added those records on the map within 10 $\times 10 \mathrm{~km}$ grid (Fig. 6) as historical data (Tab. $\mathrm{S} 1$ in Supplementary material).

The European red click beetle has been reported in the majority of European countries, including some countries neighbouring to Croatia (Cate 2007, 2013). Although Cate $(2007,2013)$ does not report the species for Croatia, there were few publications listing its presence in the country (Schlosser Klekovski 1887, Depoli 1928, Schimmel \& Tarnawski 2010), and several data from the collections (G. Platia collections, Igalffy, Koča and Korlević collections from NHM in Zagreb and Košćec collection from Varaždin Town Museum - Tab. S1). In the past it had often been named in different generic combinations, within genus Ludius Berthold, 1827, Steatoderus Dejean, 1833, Parallelostethus Schwarz, 1906 and Orthostethus Lacordaire, 1857 (Schimmel \& Tarnawski 2010). Of historical data Schlosser Klekovski (1887) reported both, hermit and the European red click beetles but without specific date or location of the findings, only adding Croatia as a whole and Slavonian part of the country. Schimmel \& Tarnawski (2010) in the monography of the subtribe Elaterina reported several findings of $E$. ferrugineus in Croatia belonging to $\mathrm{G}$. Platia collection, mainly from the Mediterranean biogeographical region (Kvarner region: Karlobag, Krk and Cres Islands - Tab. 2, Tab. S1 in Supplementary material). Doubtful is the record of Strbac (1983). In his dissertation about Elateridae and Carabidae in arable land of Slavonija and Baranja regions he mentioned only $L$. ferrugineus larva near Beli Manastir in Baranja region ( 5 individuals, in autumn 1981). Since the finding occurred in agricultural field this could be misidentification, but also the species could have been present if old hollow trees had been preserved at the arable field to make the shadow for workers, as was common practice in the past with less intensive mechanisation in the field. Although listed in recent literature, the presence of $E$. ferrugineus in the north-east part of Croatia in Kopački rit Nature Park has not been added in mapping analyses neither as recent nor historical data, due to the fact that it was not possible to trace back the original reference based on which this occurrence was included in list compiled by Krčmar (2014).

In Hensch Collection (Faculty of Agriculture, University of Zagreb) few specimens were collected in Gorica, but since there are few localities in Croatia and as well in Slovenia and in NE Italy, with this same name, Gorica as location has not been added on the map. Beside hermit species, Franjo Košćec Collection of Varaždin City Museum contains specimens of the European red click beetle (Linnaeus, 1758) collected outside of Croatia, in St. Paul in Carniolia. Other collections such as Karaman's collection (Museum in Split), then Mikšić, Novak and Weingartner collections (in NHM in Zagreb) and collections in the Hungarian Natural History Museum in Budapest, according to museum curators and entomologists do not contain E. ferrugineus exemplars.

In our field studies, E. ferrugineus was lured mainly by pheromones of hermit beetle, though it was not a target species. The same pheromones and flight intercept traps were used in study of Batrnek et al. (2017) in Osijek Town Park where seven individuals of $E$. ferrugineus were caught (Tab. 2). On the other hand, catch of E. ferrugineus at Mt. Učka using tree traps baited with wine flavoured with vanilla was most probably accidental, although P. Rapuzzi collected one specimen in Kvarner region, using wine-traps exposed in period from June $8^{\text {th }}$ until July $8^{\text {th }}$ in 2008 (G. Platia, personal communication). However, we suggest pheromone traps for further research on the distribution of the species.

Male-produced sex pheromone of hermit beetle showed very good results as kairomone for females of $E$. ferrugineus, as well as female-produced sex pheromone of E. ferrugineus to attract conspecific males (Barševskis \& Nitcis 2011, Larsson \& Svensson 2011, Musa et al. 2013, Zauli et al. 2014).

Adults of hermit and the European red click beetle are active from the end of June to the end of August (Ranius et al. 2005, Barševskis \& Nitcis 2011) therefore observations in Mt. Učka and Mt. Papuk might represent the beginning of seasonal activity of adult beetles, since both surveys ended at the beginning of July, while the project at the Plitvice Lakes area started at the end of June and finished at the beginning of August. Although $O$. barnabita has been recorded at Papuk Nature Park, E. ferrugineus was not detected. The reason could be that male-produced sex pheromone of hermit beetles used in the research attracts both sexes of hermit beetle but only females of $E$. ferrugineus who emerge later in the season. Another possible explanation relies on the fact that $E$. ferrugineus females react to kairomone only after the mating (Zauli et al. 2014) and possibly by that time the field sampling ended.

\section{Habitat suitability map - potential use and constraints}

Since the purpose of this survey was primarily to establish baseline data of the occurrences of hermit beetles and subsequent monitoring activities at Natura 2000 sites, the data collected had some limitations as to the lack of unbiased random sampling and sample size, which are both quite frequent with data collected in the 
field, especially on rare and/or endangered species. However, analyses of the data collected, for O. barnabita and E. ferrugineus, provided interesting results. Osmoderma barnabita was the target species for this survey, and $E$. ferrugineus has been observed as a "bonus". This resulted in a much larger number of input data for $O$. barnabita (19 localities) than for E. ferrugineus (12 localities). Interestingly, when using historical data, the hermit beetle again had much more data (33 localities) than the European red click beetle (8 localities). Contrary to a number of current data on its occurrence, the MaxEnt models resulted in much larger areas of habitats predicted for E. ferrugineus than for $O$. barnabita. Even testing with the historical data, resulted in that majority of historical hermit beetle data spatially coincide with current MaxEnt European red click beetle model. Having in mind the biology of both species, where $E$. ferrugineus can predate on other species besides the hermit beetle, could support obtained discrepancies, as E. ferrugineus with smaller input data set resulted in larger predicted suitable areas than those of the hermit beetle. Smaller sample size could affect predicted models in sense of larger suitable areas, but MaxEnt is rather robust in comparison to other algorithms (Wisz et al. 2008). Oleksa et al. (2013, 2015) analyzed dispersal abilities of Osmoderma barnabita and Protaetia marmorata marmorata (Fabricius, 1792) (Cetoniinae), both connected to tree hollows, and their larval predator, E. ferrugineus. Their results imply that dispersal distance of more specialized species is more restricted than those of generalists. Dispersal differences could support our findings that habitats suitable for hermit beetle may also host the red click beetle, but all habitats occupied by the red click beetle may not fit for the hermit beetle.

Environmental response curves (Fig. 5) of both species are adherent with such trends, indicating that E. ferrugineus has much wider environmental envelopes in which it can occur. The latter could explain obtained results when comparing historical records with that of MaxEnt models obtained based on current data. Surrogacy is a well-known concept used in various ways (Saetersdal et al. 2004, Molloy et al. 2017), and it seems that it can be used here, at least for $O$. barnabita as a surrogate for $E$. ferrugineus. Spatial overlap of predicted suitable habitats for two beetles conforms in part to the protected areas in Croatia (Fig. 6). In the National Parks commercial logging is not admitted, while in the Nature Parks (less strict category of protection) numerous conservation measures have been prescribed, e.g., leaving a certain amount of dead wood per hectare (which is a necessary habitat for the saproxylic beetles - Mason et al. 2003, New 2010). All these are pointing that MaxEnt habitat suitability models spatially coincide with areas in which management practice should promote sustainability of the microhabitats suitable for the saproxylic beetles. Furthermore, hermit beetle is "not an easy to record" species, which can use even nonwoodland habitats (Dodelin et al. 2017). Hence, knowledge of its populations, in particular in forest stands, may provide information for appropriate management of the forests that should ensure hermit beetle survival.

\section{Conclusions}

The distribution models predicted significantly larger area potentially suitable to $E$. ferrugineus than to $O$. barnabita. This may imply that all habitats suitable for $O$. barnabita are also suitable for E. ferrugineus, but only part of habitats that fit to E. ferrugineus may host $O$. barnabita. Based on this, it seems that $O$. barnabita can be used as surrogate species for $E$. ferrugineus. Due to the fact that the pheromone-baited traps designed for the hermit beetle were used for the first time in Croatia, further observations can be expected by the application of pheromones directed to both species in future surveys within the EU Habitat Directive actions, as was the case in the other EU Member States. Given the substantial lack of systematic field studies of both species in this part of Europe, the data presented can contribute in directing further studies and extending general knowledge of the distribution and habitat preferences of these species.

\section{List of abbreviations}

The following abbreviations have been used throughout the paper:

- a.s.l. - above sea level;

- leg - legit;

- coll - collection;

\section{Acknowledgments}

We would like to thank to: Croatian Ecological Society for their logistic support, colleagues A. Smoković, B. Špadina and M. Knjaz, M. Doboš, I. Špoljarić, K. Culinović and rangers from Plitvice Lakes National Park and Papuk Nature Park for their help during the field sampling; $G$. Platia for providing data from his collection and valuable suggestions on species distribution; S. Bowden (Oak-fortress Proofreading International) for the linguistic revision of the manuscript, G. Nardi and two reviewers whose comments and suggestions substantially improved the manuscript.

This project was financed by Croatian Agency of Environment and Nature (HAOP), Papuk NP and Plitvice Lakes NP.

Permission for performing field work was obtained from Nature and National Parks authorities and Croatian Ministry of environment and nature protection.

\section{Authors' contribution}

LSJ, IR, FK and AP carried out the field measurements, SDJ performed the statistical analysis and habitat suitability models, LSJ conceived the study and together with coauthors wrote the manuscript.

\section{References}

Alexander K, Buche B, Dodelin B, Schlaghamersky J (2010). Osmoderma barnabita. The IUCN Red List of Threatened Species 2010: e.T157901 A5169119, Website. - doi: 10.2305/IUCN.UK.20101.RLTS.T157901A5169119.en

Audisio P, Brustel H, Carpaneto GM, Coletti G, Mancini E, Piattella E, Trizzino M, Dutto M, Antonini G, De Biase A (2007). Updating the taxonomy and distribution of the European Osmoderma, and strategies for their conservation. Fragmenta Entomologica 39 (2): 273-290. - doi: 10.4081/fe.2007.124

Audisio P, Brustel H, Carpaneto GM, Coletti G, Mancini E, Trizzino M, Antonini G, De Biase A (2009). Data on molecular taxonomy and genetic diversification of the European Hermit beetles, a species complex of endangered insects (Coleoptera: Scarabaeidae, Cetoniinae, Osmoderma). Journal of Zoological Systematics and Evolutionary Research 47: 88-95. - doi: 10.1111/j.1439-0469.2008.00475.x

Barševskis A, Nitcis M (2011). Elater ferrugineus Linnaeus, 1758 (Coleoptera: Elateridae) - a new species of the fauna of Latvia. Baltic Journal of Coleopterology 11 (2): 187-195. [online] URL: http://bjc.sggw.waw.pl/arts/2011v11n2/6.pdf

Batrnek K, Bjelovuk D, Deže D, Kljajić K (2017). U potrazi za saproksilnim kornjašima [Searching for saproxylic beetles]. In: Book of abstracts of the $6^{\text {th }}$ Symposium "Kopački rit - past, present future” (Ozimec et al. eds), Tikveš (Croatia) 2829 Sep 2017. Kopački Rit Nature Park Pub., Mali Sakadaš, Croatia, pp. 21. [in Croatian]

Borhidi A (1963). Die Zönologie des Verbandes Fagion Illyricum [Zonation of the Fagion illyricum associations]. 1. Allg. Teil. Acta Botanica Academiae Scientiarum Hungarica 9: 259-297. [in German]

Cálix M, Alexander KNA, Nieto A, Dodelin B, Soldati F, Telnov D, Vazquez-Albalate $X$, Aleksandrowicz $\mathrm{O}$, Audisio $\mathrm{P}$, Istrate $\mathrm{P}$, Jansson $\mathrm{N}$, Legakis A, Liberto A, Makris C, Merkl O, Mugerwa Pettersson R, Schlaghamersky J, Bologna MA, Brustel H, Buse J, Novák V, Purchart L (2018). European red list of saproxylic beetles. IUCN, Brussels, Belgium, pp. 13.

Cate PC (2007). Family Elateridae. In: “Catalogue of Palaearctic Coleoptera: Elateroidea, Derodontoidea, Bostrichoidea, Lymexyloidea, Cleroidea and Cucujoidea", vol. 4 (Löbl I, Smetana A eds). Apollo Books, Stenstrup, Denmark, pp. 89-207.

Cate PC (2013). Fauna Europaea: Elateridae. In: "Fauna Europaea: Coleoptera I" (Alonso-Zarazaga MA ed). Fauna Europaea version 2017.06. [online] URL: https://fauna-eu.org

Depoli G (1928). I coleotteri della Liburnia. Parte III. Diversicornia [Beetles (Coleoptera) of Liburnia. Part III. Diversicornia]. Fiume (Rijeka), Società di Studi Fiumani 6: 208-243. [in Italian]

Delić A, Mihoci I, Kučinić M (2017). Prilog poznavanju faune člankonožaca (Arthropoda) Ogorske Svilaje [Contribution to knowledge of atrhropod fauna of Ogorje, Svilaja region]. In: "Zupa Ogorje - putovima života i vjere izmedu Svilaje i Moseća" [Ogorje Parish - life and religion in Svilaja and Moseć reagion] (Kapitanović V ed). Mediaprint - tiskara Hrastić Itd., Zagreb, 
Croatia, pp. 141-161. [in Croatian]

Dodelin B, Gaudet S, Fantino G (2017). Spatial analysis of the habitat and distribution of Osmoderma eremita (Scop.) in trees outside of woodlands. In: "Monitoring of saproxylic beetles and other insects protected in the European Union" (Campanaro A, Hardersen S, Sabbatini Peverieri G, Carpaneto GM eds). Nature Conservation 19: 149-170. - doi: 10.3897/nature conservation.19.12417

EEA (2013). Croatia shapefile and Croatia spatialite. EEA Reference grid, Web site. [online] URL: http://www.eea.europa.eu/data-and-map s/data/eea-reference-grids-2

European Commission (1992). Council Directive 92/43/EEC of 21 May 1992 on the conservation of natural habitats and of wild fauna and flora. Official Journal of the European Community 206 (1): 7-50. [online] URL: http://eur-lex.eu ropa.eu/legal-content/EN/TXT/?uri=CELEX:31992 L0043

Freude H, Harde KW, Lohse GA (1979). Die Käfer Mitteleuropas, Band 6. Diversicornia [Beetles of Central Europe, Volume 6. Diversicornia]. Goecke and Evers, Krefeld, Germany, pp. 367. [in German]

Guisan A, Weiss SB, Weiss AD (1999). GLM versus CCA spatial modelling of plant species distribution. Plant Ecology 143: 107-122. - doi: 10.1023/A: 1009841519580

Han T, Park IG, Kim K, Ivanov S, Park H (2017). Identification of the South Korean hermit beetle (Coleoptera: Scarabaeidae: Cetoniinae). Korean Journal of Applied Entomology 56 (3): 229-239. - doi: 10.5656/KSAE.2016.08.0.036

Harvey DJ, Hawes CJ, Gange AC, Finch P, Chesmore D, Farr I (2011). Development of non-invasive monitoring methods for larvae and adults of the stag beetle, Lucanus cervus. Insect Conservation and Diversity 4: 4-14. - doi: 10.1111/j.17 52-4598.2009.00072.x

Horvat I, Glavač V, Ellenberg H (1974). Vegetation Südosteuropas [Vegetation of SoutheastEurope]. Gustav Fischer Verlag, Stuttgart, pp. 768. [in German]

Jelaska SD, Antonić O, Nikolić T, Hršak V, Plazibat M, Krian J (2003). Estimating plant species occurrence in MTB/64 quadrants as a function of DEM-based variables a case study for Medvednica Nature Park, Croatia. Ecological Modelling 170 (2-3): 333-343. - doi: 10.1016/So3 04-3800(03)00237-0

Katušić L, Jelaska SD, Šerić Jelaska L (2017). Monitoring of saproxylic beetles in Croatia: following the path of the stag beetle. In: "Monitoring of saproxylic beetles and other insects protected in the European Union" (Campanaro A, Hardersen S, Sabbatini Peverieri G, Carpaneto GM eds). Nature Conservation 19: 39-56. doi: 10.3897/natureconservation.19.12683

Koča GJ (1900). Prilog fauni gore Papuka i njegove okoline [Contribution to fauna of Mt. Papuk and its surroundings]. Glasnik Hrvatskoga naravoslovnoga društva 12 (1-3): 100-134. [in Croatian]

Krčmar S (2014). List of insect fauna (Insecta) of Kopački Rit Nature Park (NE Croatia). Türkiye Entomoloji Bülteni 4 (1): 15-39.

Larsson MC, Hedin J, Svensson GP, Tolasch T, Francke W (2003). Characteristic odour of Osmoderma eremita identified as a male-released pheromone. Journal of Chemical Ecology 29: 575-587. - doi: 10.1023/A:1022850704500

Larsson MC, Svensson GP (2011). Monitoring spatiotemporal variation in abundance and dispersal by a pheromone-kairomone system in the threatened saproxylic beetles Osmoderma eremita and Elater ferrugineus. Journal of Insect Conservation 15 (6): 891-902. - doi: 10.1007/s108 41-011-9388-5

Merzijevskis A, Tamutis V (2010). Elater ferrugineus Linnaeus, 1758 (Coleoptera: Elateridae) - a new species for Lithuania. Acta Zoologica Lituanica 20: 207-210. - doi: 10.2478/v10043-010-003 6-1

Mason F, Nardi G, Tisato M (2003). Legno morto: una chiave per la biodiversità [Dead wood: a key to biodiversity]. In: Proceedings of the Symposium "Dead wood: a key to biodiversity" (Mason F, Nardi G, Tisato M eds). Mantova (Italy) 29- 31 May 2003. Sherwood - Foreste ed Alberi Oggi 95 (suppl. 2): 99. [in Italian]

Maurizi E, Campanaro A, Chiari S, Maura M, Mosconi F, Sabatelli S, Zauli A, Audisio P, Carpaneto GM (2017). Guidelines for the monitoring of Osmoderma eremita and closely related species. In: "Guidelines for the Monitoring of the Saproxylic Beetles protected in Europe" (Carpaneto GM, Audisio P, Bologna MA, Roversi PF, Mason F eds). Nature Conservation 20: 79-128. - doi: 10.3897/natureconservation.20.12658

Molloy SW, Davis RA, Dunlop JA, van Etten EJB (2017). Applying surrogate species presences to correct sample bias in species distribution models: a case study using the Pilbara population of the Northern Quoll. Nature Conservation 18: 2746. - doi: 10.3897/natureconservation.18.12235

Musa N, Andersson K, Burman J, Andersson F, Hedenström E, Jansson N, Paltto $H$, Westerberg L, Winde I, Larsson MC, Bergman KO, Milberg $P$ (2013). Using sex pheromone and a multi-scale approach to predict the distribution of a rare saproxylic beetle. PLoS ONE 8 (6): e66149. - doi: 10.1371/journal.pone.0066149 New TR (2010). Beetles in conservation. Wiley Blackwell, Oxford, UK, pp. 237.

Nieto A, Alexander KNA (2010). European red list of saproxylic beetles. Publications Office of the European Union and International Union for Conservation of Nature, Luxembourg, pp. 54.

Oleksa A, Chybicki IJ, Gawronski R, Svensson GP, Burczyk J (2013). Isolation by distance in saproxylic beetles may increase with niche specialization. Journal of Insects Conservation 17: 219-233. - doi: 10.1007/s10841-012-9499-7

Oleksa A, Chybicki IJ, Larsson MC, Svensson GP, Gawronski R (2015). Rural avenues as dispersal corridors for the vulnerable saproxylic beetle Elater ferrugineus in a fragmented agricultural landscape. Journal of Insects Conservation 19: 567-580. - doi: 10.1007/s10841-015-9778-1

Platia G, Liberto A, Mazzei A (2015). Elateridae. In: "A Red List of Italian Saproxylic Beetles: Taxonomic Overview, Ecological Features and Conservation Issues (Coleoptera)" (Carpaneto GM, Baviera C, Biscaccianti AB, Brandmayr P, Mazzei A, Mason F, Battistoni A, Teofili C, Rondinini C, Fattorini S, Audisio P eds). Fragmenta Entomologica 47 (2): 53-126. - doi: 10.4081/fe.20 15.138

Phillips SJ, Anderson RP, Schapire RE (2006). Maximum entropy modelling of species geo- graphic distributions. Ecological Modelling 190: 231-259. - doi: 10.1016/j.ecolmodel.2005.03.026 Ranius T, Aguado LO, Antonsson K, Audisio P, Ballerio A, Carpaneto GM, Chobot $K$, Gjurašin B, Hanssen O, Huijbregts $\mathrm{H}$, Lakatos F, Martin O, Neculiseanu Z, Nikitsky NB, Paill W, Pirnat A, Rizun V, Ruicãnescu A, Stegner J, Süda I, Szwalko P, Tamutis V, Telnov D, Tsinkevich V, Versteirt V, Vignon V, Vögeli M, Zach P (2005). Osmoderma eremita (Coleoptera, Scarabaeidae, (etoniinae) in Europe. Animal Biodiversity and Conservation 28 (1): 1-44.

Ranius T, Nilsson SG (1997). The habitat of Osmoderma eremita Scop. (Coleoptera: Scarabaeidae), a beetle living in hollow trees. Journal of Insect Conservation 1: 193-204. - doi: 10.1023/A:1018416000766

Rojko I, Koren T (2011). Additions to the faunal list of Scarabaeoid beetles (Insecta, Scarabaeoidea) of the River Zrmanja and its surroundings, Croatia. Annales, Seria Historia Naturalis 21 (2): 125-132.

Šerić Jelaska L (2013). Stag beetle monitoring program developed within IPA MANMON project "Natura 2000 Management and Monitoring, Croatia” (EUROPEAID/129747/D/SER/ HR). Croatian Environment and Nature Agency, Zagreb, Croatia, pp. 26.

Strbac P (1983). Fauna, bionomija i morfološkotaksonomske karakteristike klisnjaka i trčuljaka (Coleoptera: Elateridae i Carabidae) u agroekološkim uslovima Slavonije i Baranje [Faunistic, bionomic, morphological and taxonomic characteristics of click and ground beetles (Coleoptera: Elateridae and Carabidae) in the agro-ecological conditions of Slavonia and Baranja]. PhD thesis, Josip Juraj Strossmayer University, Faculty of Agriculture, Osijek, Croatia, pp. 216. [in Croatian]

Sadeghi M, Malekian M (2017). The Persian squirrel of Kurdistan Province, western Iran: what determines its geographic distribution? Mammalia 81 (3): 309-314. - doi: 10.1515/mammalia2015-0166

Saetersdal M, Gjerde I, Blom HH, Ihlen PG, Myrseth EW, Pommeresche R, Skartveit J, Solhoy T, Aaas O (2004). Vascular plants as a surrogate species group in complementary site selection for bryophytes, macrolichens, spiders, carabids, staphylinids, snails, and wood living polypore fungi in a northern forest. Biological Conservation 115: 21-31. - doi: 10.1016/Sooo6-32 07(03)00090-9

Schimmel R, Tarnawski D (2010). Monograph of the subtribe Elaterina (Insecta: Coleoptera: Elateridae: Elaterinae). Genus 21 (3): 325-487. [online] URL: http://quelestcetanimal-lagalerie. com/wp-content/uploads/2016/11/Schimmel_Ela terina_low.pdf

Schlosser Klekovski JK (1887). Fauna kornjaša trojedne kraljevine [Fauna of beetles in Kingdom of Croatia-Slavonia-Dalmatia]. Yugoslavian Academy of Science and Art, Zagreb, Kingdom of Croatia-Slavonia-Dalmatia, pp. 342. [in Croatian]

Sparacio I (2000). Osservazioni sulle Osmoderma Le Peletier et Audinet-Serville europee con descrizione di una nuova specie dell'Italia meridionale (Coleoptera Cetoniidae) [Observations of European Osmoderma Le Peletier et AudinetServille with description of new species in 
Southern Italy]. II Naturalista Siciliano 24 (3-4): 225-239. [in Italian] [online] URL: http://www. edizionidanaus.com/pdf/ENTOMOLOGIASISTE MATICA/Sparaciol.,2000-Osmodermaeuropee condescrizionediunaspeciedell'italiameridional e.pdf

Svensson GP, Larsson MC (2008). Enantiomeric specificity in a pheromone-kairomone system of two threatened saproxylic beetles, Osmoderma eremita and Elater ferrugineus. Journal of Chemical Ecology 34: 189-197. - doi: 10.1007/ s10886-007-9423-x

Vrezec A, Ambrozič S, Kapla A (2013). An overview of sampling methods tests for monitoring schemes of saproxylic beetles in the scope of
Natura 2000 in Slovenia. In: "Saproxylic beetles in Europe: monitoring, biology and conservation" (Jurc M ed). Slovenian Forestry Institute, Silva Slovenica, Ljubljana, Slovenia, pp. 73-90. Wisz MS, Hijmans RJ, Li J, Peterson AT, Graham $\mathrm{CH}$, Guisan A, NCEAS Predicting Species Distributions Working Group (2008). Effects of sample size on the performance of species distribution models. Diversity and Distributions 14: 763773. - doi: 10.1111/j.1472-4642.2008.00482.x

Zauli A, Chiari S, Hedenström E, Svensson GP, Carpaneto GM (2014). Using odour traps for population monitoring and dispersal analysis of the threatened saproxylic beetles Osmoderma eremita and Elater ferrugineus in central Italy.
Journal of Insect Conservation 18 (5): 801-813. doi: 10.1007/s10841-014-9687-8

\section{Supplementary Material}

Tab S1 - Historical records of hermit and the European red click beetles in Croatia dating before 2002, based on Croatian museums and literature data, added on the map in $10 \times 10 \mathrm{~km}$ grid and overlapped with models using recent findings listed in Tab. 1.

Link: Seric_2753@supploo1.pdf 